\title{
Primary frequency control applied to the wind turbine based on the DFIG controlled by the ADRC
}

\author{
Issam Minka ${ }^{1}$, Ahmed Essadki ${ }^{2}$, Sara Mensou ${ }^{3}$, Tamou Nasser ${ }^{4}$ \\ 1,2,3 Electrical Engineering, Department of ENSET, Mohammed V University, Morocco \\ ${ }^{4}$ Department Communication Networks, Department of ENSIAS, Mohammed V University, Morocco
}

\begin{tabular}{l}
\hline Article Info \\
\hline Article history: \\
Received Dec 7, 2018 \\
Revised Feb 27, 2019 \\
Accepted Mar 10, 2019 \\
\hline Keywords: \\
ADRC \\
DFIG \\
MPPT \\
Pitch angle control \\
Primary frequency control \\
Wind turbine \\
\hline
\end{tabular}

\begin{abstract}
In this paper, we study the primary frequency control that allows the variable speed Aeolian to participate in the frequency regulation when a failure affects the network frequency. This method based on the control of the generator rotational speed or the control of pitch angle makes it possible to force the wind turbine to produce less power than its maximum available power, consequently we will create an active power reserve. This wind turbine must inject into the grid a part of its power reserve when the frequency drops, in contrary the wind turbine reserves more of energy. So, this work presents the performances of this control strategy for the different wind speed value. The results are obtained by a simulation in the MATLAB/SIMULINK environment.
\end{abstract}

Copyright (C) 2019 Institute of Advanced Engineering and Science. All rights reserved.

Corresponding Author:

Issam Minka,

Department of Electrical Engineering, ENSET

Mohammed V University Rabat, Morocco.

Email: issamminka@gmail.com

\section{INTRODUCTION}

Wind energy has experienced a strong development in the last decade in the world, which leads to an increasing insertion of this energy in the electrical networks [1-4]. However, the intermittent nature and irregularity of wind generation will impact the stability of the networks and the quality of energy produced and provided to users [5-6]. This situation leads to the definition of new technical connection conditions requiring new wind farms to contribute in the same way as conventional power plants, to the system services of the electricity networks to which they are connected [5-7]. Among these services, the frequency regulation of the network. So our goal is to synthesize a command to stabilize the frequency of the network after a change of frequency caused by an imbalance between production and consumption at its reference value. This control strategy is called the primary frequency control [6].

In this work we use the Active Disturbance Rejection Control (ADRC), which allowsthe stability of the Wind Energy Conversion System (WECS) based on a Double Fed Induction Generator (DFIG), this control is applied to the Rotor Side Converter (RSC) and the Grid Side Converter (GSC) as shown in the Figure 1 [8-10]. Wealso study the frequency control strategy mentioned before in order to force the Aeolian to participate in the frequency setting,according to the operating zone of the wind turbine two control strategies are presented, the first one when the speed of rotation and the power do not exceed their maximum values, so the control of the active power of the wind turbine is made by an action on the electromagnetic torque and by the control of the turbine rotational speed,the second one when we have a high wind speed, the control of power extracted from the wind is done by an action on the angle of orientation of the blades. Finally we present the simulation results of these controls and their interpretations. 


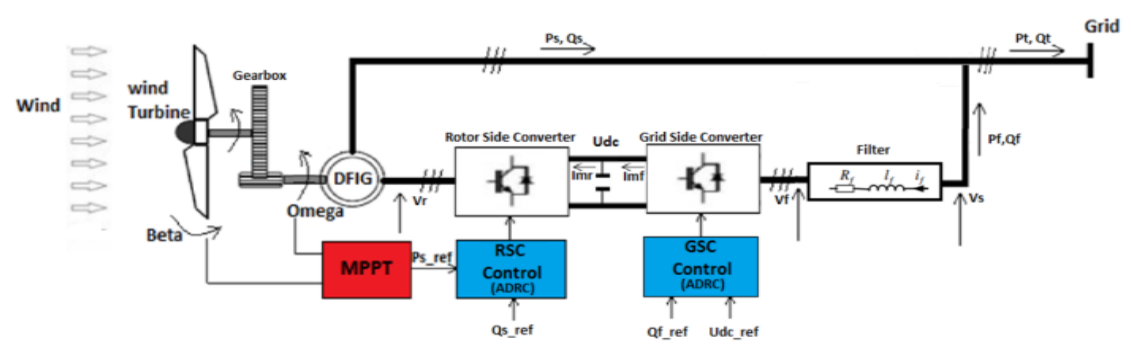

Figure 1. The wind energy conversion system structure

\section{PRIMARY FREQUENCY CONTROL}

Unlike conventional production systems, DFIG-based wind turbines have no relation to the grid frequency because of their variable speed operation, hence zero inertial response, and they do not participate in frequency stabilization.

To involve the Aeolian system in the primary setting of the grid frequency, it must produce an electrical power less than its maximum available power $P_{M P P T}$ when the grid frequency is in a normal range around the nominal frequency in order to create a primary reserve. An instantaneous imbalance between production and consumption is synonymous with a frequency variation, so when the frequency drops, the wind turbine must provide a portion of its power reserve $\Delta P$ which is proportional to the variation of the frequency $\Delta f$ to the grid. This portion power injected is based on the statism $\delta$ curve as shown in Figure 2, which is not fixed and depends on the maximum available power and the wind speed [11].

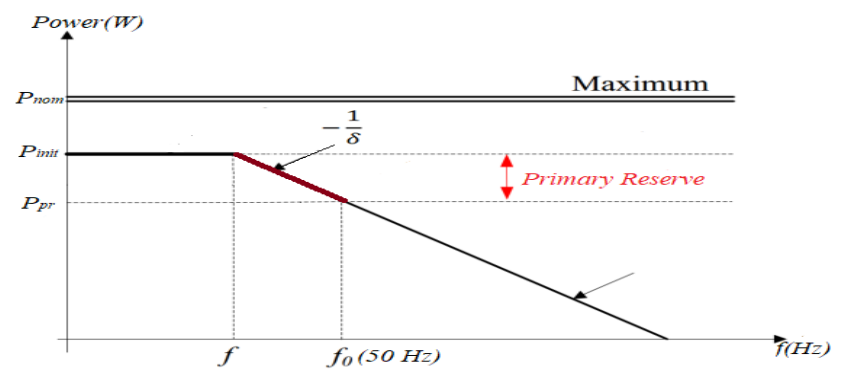

Figure 2. The statism curve

Usually the calculation of statism $\delta$ is defined by the following expression:

$$
\delta=\frac{\frac{f(t)-f_{0}}{f_{0}}}{\frac{P_{\text {init }}(t)-P_{p r}}{P_{\text {nom }}}}
$$

Where $f$ is a wind group frequency, $f_{0}$ is a network reference frequency, $P_{\text {init }}$ the instantaneous power produced by a group, $\mathrm{P}_{\mathrm{pr}}$ programmed reserve power and $\mathrm{P}_{\text {nom }}$ is a nominal power of wind turbine.

So two means of control are possible to lower the value of the $C_{p}$ coefficient of power (i.e. active power) [12]: Either by an acceleration of the speed of the turbine, or by an increase of the angle of orientation of the blades (pitch angle).

\subsection{Active power management by controlling the mechanical rotation speed}

This control is used when the wind speed is below the rated speed that the turbine can withstand; the principle of this method is to create a $(1-\mathrm{K}) \mathrm{P}_{\text {init }}$ power reserve while adjusting the electromagnetic torque of the generator and maintain the pitch angle at $0^{\circ}$ as shown in Figure 3 [13-15].

Int J Pow Elec \& Dri Syst, Vol. 10, No. 2, June 2019 : 1049-1058 


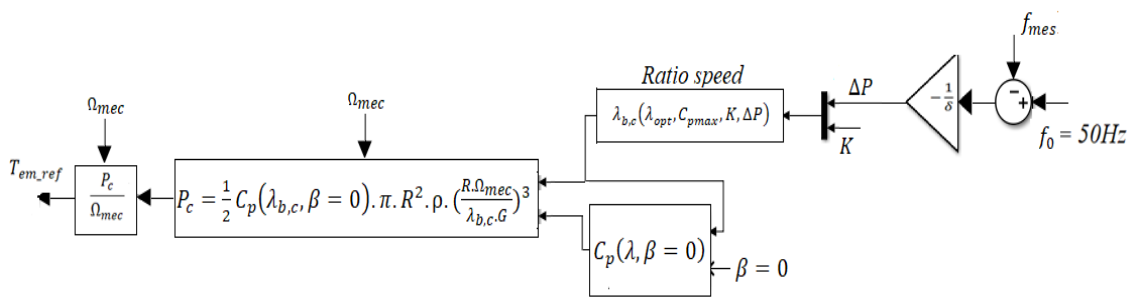

Figure 3. Frequency control loop of a variable speed wind turbine system

$\mathrm{G}$ : is the coefficient multiplier of Gearbox

As shown in Figure 4 the primary reserve is made by reducing the power coefficient with a shift from operating point $\mathrm{A}$ to point $\mathrm{B}$ and by increasing the mechanical rotational speed (i.e. increasing the ratio speed $\lambda$ ) [16-19].The point A corresponds to the maximum power extracted from the wind and to the optimal rotation speed, while the operating point B corresponds to the power created after reservation. When there is an imbalance of the production-consumption ratio, that is to say a frequency instability the operating point move towards another operating point $\boldsymbol{C}$ to inject into the network the quantity of power $\Delta \mathrm{P}$ which corresponds to this variation.

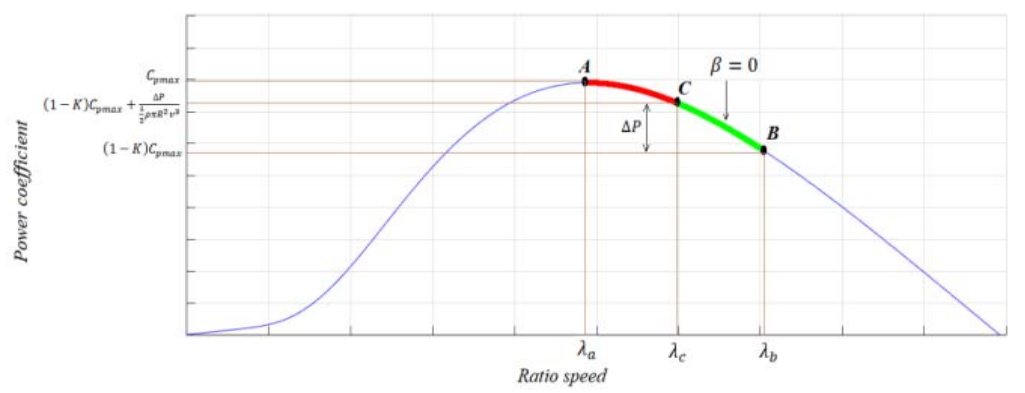

Figure 4. Displacement of the operating point by increasing the turbine rotation speed

The aerodynamic power at point $\boldsymbol{C}$ is determined by the (16) [11]:

$$
P_{c}=(1-K) P_{M P P T}+\Delta P
$$

With:

$$
\Delta \mathrm{P}=-\frac{1}{\delta}\left(\mathrm{f}_{0}-\mathrm{f}_{\mathrm{mes}}\right)=-\frac{1}{\delta} \Delta \mathrm{f}
$$

We deduce the power coefficient at point $\boldsymbol{C}$ :

$$
C_{p}\left(\lambda_{c}, \beta=0\right)=(1-K) C_{p \max }+\frac{\Delta P}{\frac{1}{2} \rho \pi R^{2} v^{3}}
$$

We express the power coefficient $C_{p}(\lambda, \beta=0)$ by its interpolation polynomial of degree 2 as a function of $\lambda$ and $\beta=0^{\circ}[11]$ :

$$
C_{p}(\lambda)=-0.0179 \lambda^{2}+0.2744 \lambda-0.5522
$$

The resolution of (4) by replacing $C_{p}\left(\lambda_{c}, \beta=0\right)$ by its interpolation polynomial of the (5) makes it possible to express the speed ratio at the point $C$ : 


$$
\lambda_{C}=\lambda_{o p t}+\frac{-\left(a_{1}+2 . a_{2} \lambda_{o p t}\right)-\sqrt{\left(a_{1}+2 . a_{2} \lambda_{o p t}\right)^{2}-4 . a_{2}\left(a_{2} \lambda_{o p t}{ }^{2}+a_{1} \lambda_{o p t}+a_{0}+\alpha\right)}}{2 . a_{2}}
$$

With:

$$
\left\{\begin{array}{c}
\alpha=\frac{\Delta P}{\frac{1}{2} \rho \pi R^{2} v^{3}} \\
a_{0}=-0.5522 \\
a_{1}=0.2744 \\
a_{2}=-0.0179
\end{array}\right.
$$

When the grid frequency is stable at $\left(f_{0}=50 \mathrm{~Hz}\right) \Delta \mathrm{P}=0$, then the operating point of the wind turbine is at point $\mathrm{B}$, consequently the power coefficient at point $\mathrm{B}$ and the speed ratio are given by:

$$
\left\{\begin{array}{c}
C_{p}\left(\lambda_{b}, \beta=0\right)=(1-K) C_{p \max } \\
\lambda_{b}=\lambda_{\text {opt }}+\frac{-\left(a_{1}+2 . a_{2} \lambda_{o p t}\right)-\sqrt{\left(a_{1}+2 . a_{2} \lambda_{o p t}\right)^{2}-4 . a_{2}\left(a_{2} \lambda_{o p t}{ }^{2}+a_{1} \lambda_{o p t}+a_{0}\right)}}{2 \cdot a_{2}}
\end{array}\right.
$$

The electromagnetic torque $\mathrm{T}_{\text {em_ref }}$ expressed by the (9), requires the wind generator to move from operating point $\boldsymbol{A}$ to point $\boldsymbol{B}$ in order to achieve a power reserve, and during a frequency imbalance, it changes the operating point from the point $\boldsymbol{B}$ to $\boldsymbol{C}$ in order to inject the corresponding power:

$$
T_{\text {em_ref }}=\frac{1}{2} \rho \pi R^{3} v^{3} C_{p}\left(\lambda_{c}\right) \frac{1}{\lambda_{c} G}
$$

\subsection{Active power management by the pitch control}

According to the power-speed characteristic Figure 5 of the wind turbine when the wind speed is high, the power captured by the turbine and its rotational speed reach their maximum values. In this case, we cannot have the desired power reserve only by increasing the rotation speed. Under these conditions and in order to create the power reserve, the speed of rotation must be kept almost close to its maximum value, and also, we added another control strategy based on the control of the orientation angle of the blades [20-22].

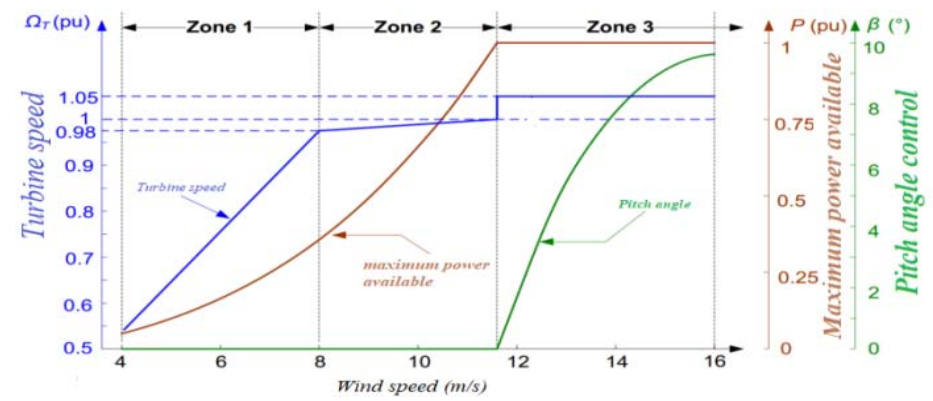

Figure 5. The power-speed characteristic

The Figure 6 shows the principle of this control which allows the displacement of the operating points on the power coefficient characteristic as a function of the ratio speed $\lambda$ and for different values of $\beta$. The operating point $\boldsymbol{A}$ corresponds to the optimal rotation speed and to the maximum power captured by the turbine $P_{M P P T}$ for $\beta=0^{\circ}$. The displacement of the operating point $\boldsymbol{A}$ to the point $\boldsymbol{B}$ which corresponds to the maximum rotation speed does not allow the creation of the desired power reserve $(1-K) P_{M P P T}$. For this purpose, by using the pitch angle control, the angle of orientation of the blades $\beta$ is increased, which makes it possible to reduce the captured power of the wind and to set the operating point at the point $\boldsymbol{E}$ that allows to create the desired power reserve [11], when we have an imbalance frequency the operating point moves from point $\boldsymbol{E}$ to $\boldsymbol{F}$ in order to inject the corresponding power. The Control loops for pitch angle control and power control are shown in the Figure 7.

Int J Pow Elec \& Dri Syst, Vol. 10, No. 2, June 2019 : 1049 - 1058 


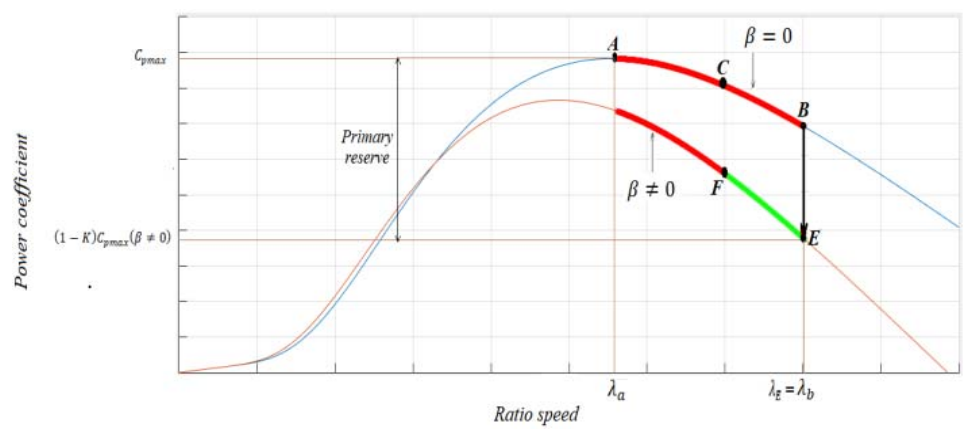

Figure 6. Displacement of the operating point by changing the angle $\beta$

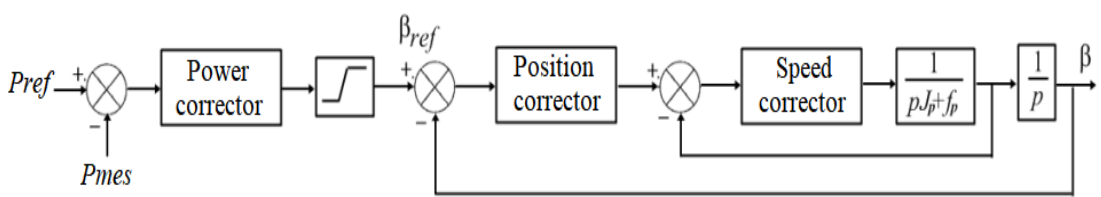

Figure 7. Block diagram of the system of orientation of the blades

The speed regulator and the power corrector are the Proportional Integral (PI) type, for the position corrector we have chosen a Proportional type corrector $(\mathrm{P})$. The saturation value of the wedging angle in position is $90^{\circ}[23]$, [24].Thereference power making it possible to decrease the angle of orientation of the blades, thus to allow the wind turbine to reserve the power or to inject into the network a quantity of power $\Delta \mathrm{P}$ is given by the following expression:

$$
P_{\text {ref }}=(1-K) P_{M P P T}+\Delta P
$$

\section{SIMULATION AND INTERPRETATIONS}

In this part we test the participation of the wind turbine controlled by ADRC at the primary frequency regulation. For that, we choose different values of the power reserve $(\mathrm{K} \%)$ and different values of wind speeds. We took the wind speedconstant during the time of simulation, the grid frequency drop with $1 \mathrm{~Hz}$ from the instant $14 \mathrm{~s}$ to the instant $19 \mathrm{~s}$, then increases by $+0.8 \mathrm{~Hz}$ from the instant $21 \mathrm{~s}$ to the instant $26 \mathrm{~s}$ Figure 8 , The statism of the primary frequency setting system is set at $4 \%$ and the DFIG and its control system are assumed ideal.

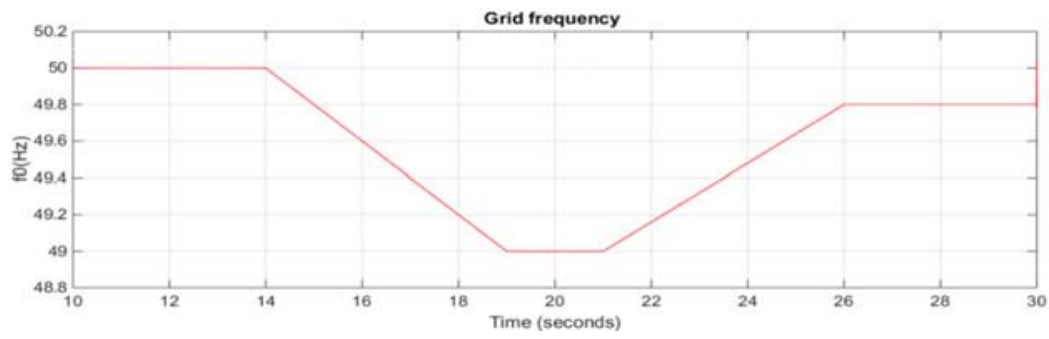

Figure 8. The grid frequency

\subsection{Evaluation of the speed control strategy}

In this case the wind speed values used is less than the nominal wind speed of the wind turbine used $(\leq 11.07 \mathrm{~m} / \mathrm{s})$ and the angle of orientation of the blades is kept at zero. From the results obtained in Figures 9 , 10,11 and 12 it is noted that the mechanical rotation speed and the electromagnetic torque force the generator to rotate at a speed higher than the optimal speed and also degrade the coefficient of power thus allowing the wind turbine to create a reserve of power. During the frequency drop create at the instant $14 \mathrm{~s}$ the

Primary frequency control applied to the wind turbine based on the DFIG ... (Issam Minka) 
electromagnetic torque begins to increase proportionally to the frequency drop, contrary to the mechanical rotation speed which decreases and causes an increase in the power coefficient (i.e. active power). From the instant $21 \mathrm{~s}$ the electromagnetic torque begins to decrease and requires the rotor to increase its rotational speed which leads to the degradation of the power coefficient and the reconstitution of the power reserve.

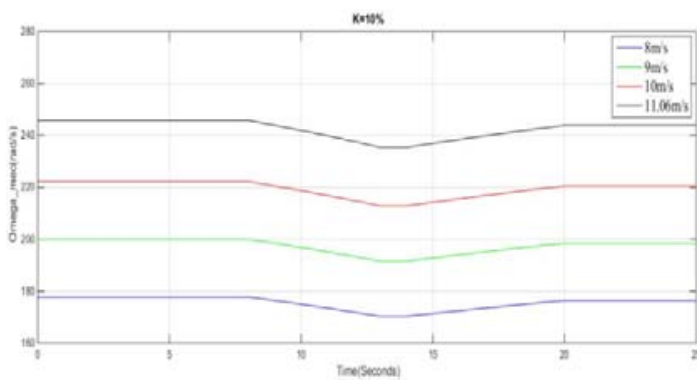

Figure 9. Mechanical rotation speed for different wind speed values and a constant value of the power reserve $(\mathrm{K}=10 \%)$

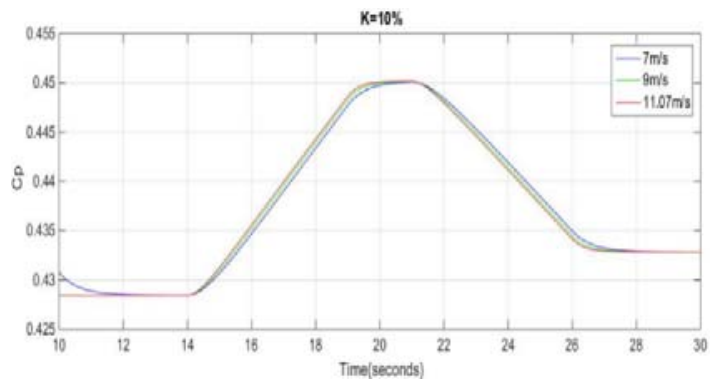

Figure 11. Power Coefficient for different wind speed values and a constant value of the power reserve $(\mathrm{K}=10 \%)$

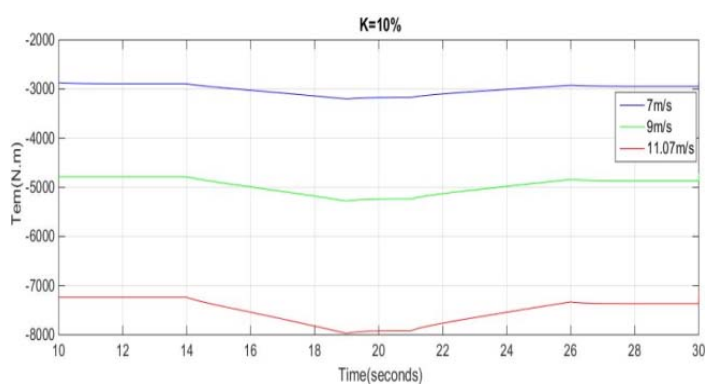

Figure 10. Electromagnetic torque for different wind speed values and a constant value of the power reserve $(\mathrm{K}=10 \%)$

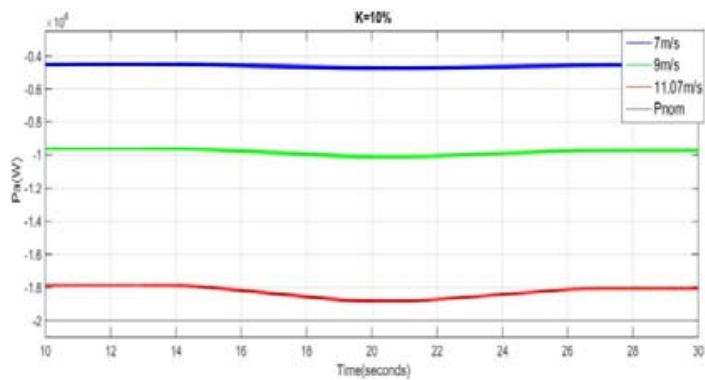

Figure 12. Active power for different wind speed values and a constant value of the power reserve $(\mathrm{K}=10 \%)$

According to the Figures 13 and 14 we also notice that the evolution of the rotational speed and the active power for the percentage of power reserve $\mathrm{K}=10 \%$ is different to those for the cases of $\mathrm{K}=15 \%$ and $\mathrm{K}=20 \%$. This difference is explained by the initial position of the operating point before the frequency default and by the non-linearity of the power-speed characteristic of the wind turbine. But the reaction of this Aeolian to the variation of frequency remains the same for all percentages of reserve taken.

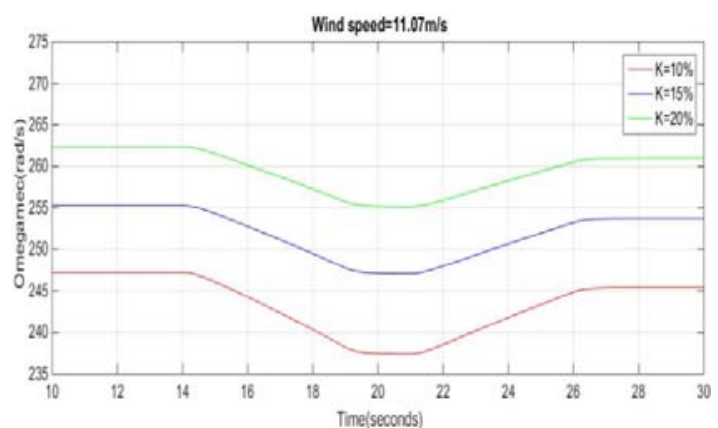

Figure 13. Mechanical rotation speed for different power reserve $(\mathrm{K} \%)$ values and a constant wind speed value

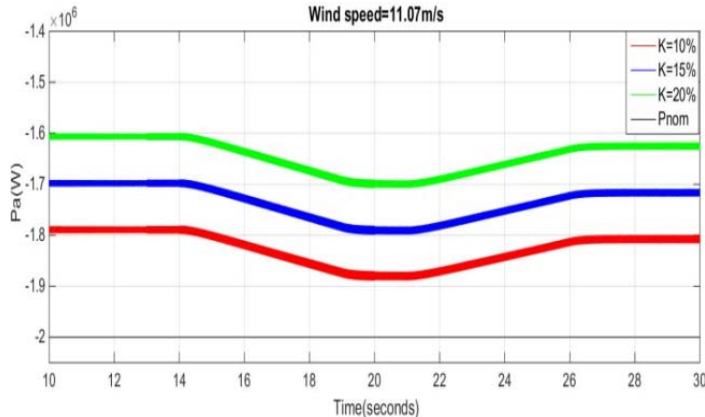

Figure 14. Active power for different power reserve ( $\mathrm{K} \%$ ) values and a constant wind speed value 


\subsection{Evaluation of the pitch angle control}

In that event the wind speed values used is superior to the nominal wind speed of the wind turbine used $(\geq 11.07 \mathrm{~m} / \mathrm{s})$.As shown in the Figure 15 , the angle $\beta$ follows its set points generated by the control loop of the blade orientation system.

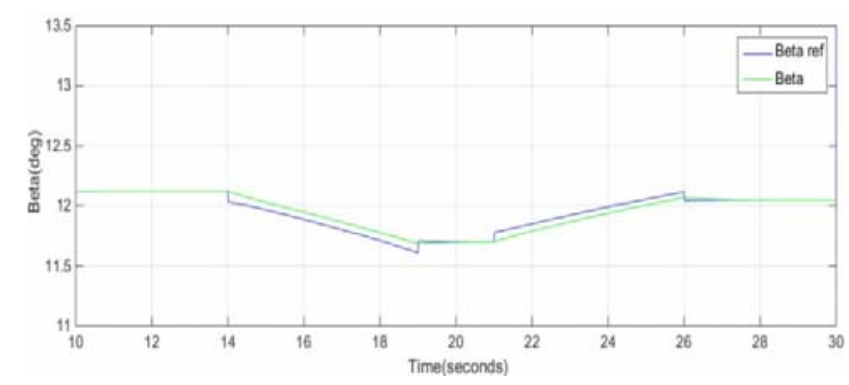

Figure 15. The angle of orientation of the blades and its reference

The Figures 17 and 18 show the evolution of active power and the mechanical rotation speed for different wind speeds and with a constant power reserve percentage. We notice that the rotation speed is close to its maximum value; therefore, moving the operating point to create a power reserve can no longer be done only by increasing the mechanical speed, then the addition of the pitch angle control is essential to create the necessary reserve. According to the Figure 16 we notice that the angle of orientation of blades increase proportionally to the wind speed.

When the frequency drop at the instant $14 \mathrm{~s}$ the pitch angle begins to decrease proportionally to the frequency drop, which decreases the mechanical rotation speed that causes an increase of power produced. From the instant $21 \mathrm{~s}$ the angle of orientation of blades begins to increase which makes it possible to increase the mechanical rotational speed which leads to the degradation of the power coefficient thus allowing to restore the power reserve.

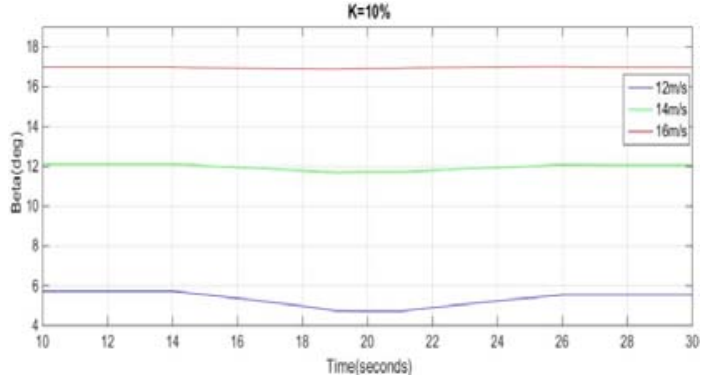

Figure 16. The angle of orientation of the blades for different wind speed values

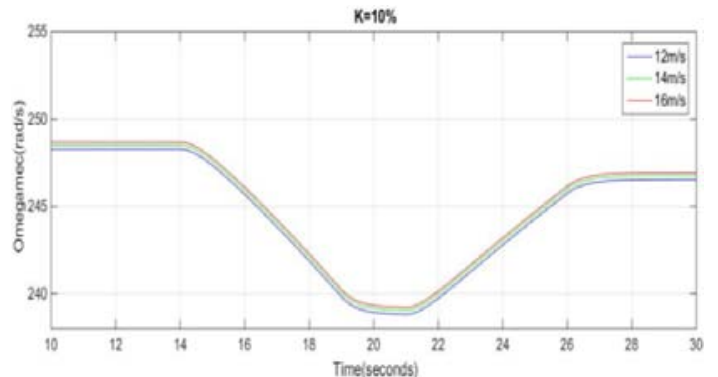

Figure 17. Mechanical rotation speed for different wind speed valuesand a constant value of the power reserve $(\mathrm{K}=10 \%)$

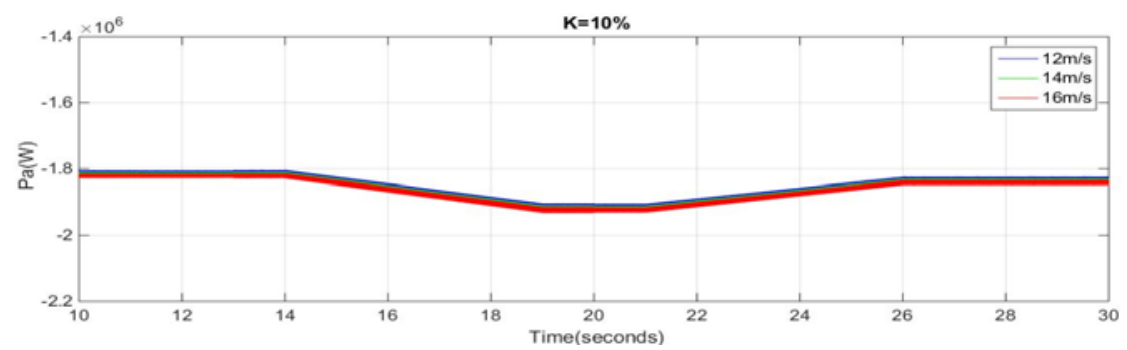

Figure 18. Active power for different wind speed values and a constant value of the power reserve $(\mathrm{K}=10 \%)$ 
As the Figures 19, 20 and 21show that for each percentage of reserve the angle of orientation of the blades is defined in order to create a power reserve, and also the mechanical rotation speed does not shift its maximum value. We notice the evolution of the mechanical rotation speed and the active power for the different percentages $(\mathrm{K} \%)$ of the power reserve are different because of the initial position of the operating point before the frequency failure and also by the increase or decrease of the angle of orientation of the blades.

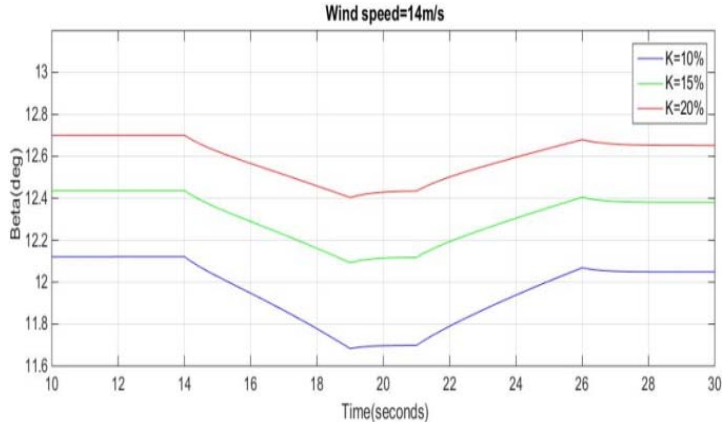

Figure 19. The angle of orientation of the blades for different power reserve $(\mathrm{K} \%)$ values

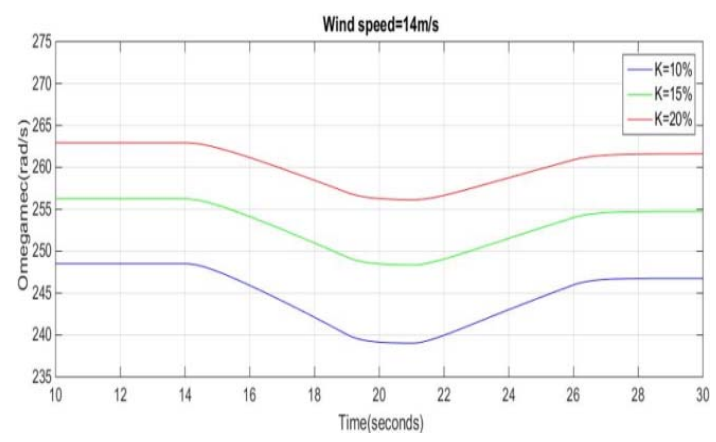

Figure 20. Mechanical rotation speed for different power reserve $(\mathrm{K} \%)$ values and a constant wind speed value

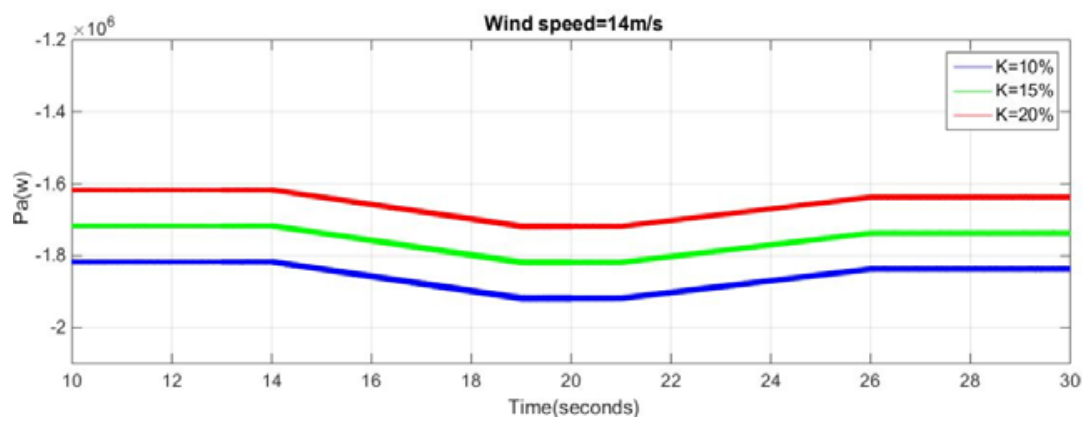

Figure 21. Active power for different power reserve (K\%) values and a constant wind speed value

\section{CONCLUSION}

In order to force the wind turbine to participate in the frequency adjustment a control strategy has been studied and developed, to operate the wind turbine in a non-optimal state to create a primary reserve for all wind speeds by using two methods, such as the control of the rotation speed via the electromagnetic torque and thus the control of the orientation angle of the blades.

The first method is used when the wind speed is lower than the nominal speed that the turbine can capture $(11.07 \mathrm{~m} / \mathrm{s})$. This control strategy is made by increasing the mechanical rotation speed via the electromagnetic torque. When the wind speed exceeds this nominal speed of the turbine, the second method is used which makes it possible to increase the angle of orientation of the blades to create a reserve of power and thus to maintain the speed of rotation and the Generator power must not exceed their maximum values.

As the results show, for all wind speed values the wind turbine produces a portion of his available power when the grid frequency is stable and releases the stored energy when the grid frequency drops to support the grid, and gradually returns to its initial value after the grid frequency has returned to its nominal value. 


\section{APPENDIX}

\begin{tabular}{cc}
\multicolumn{2}{c}{ Table 1. Parameters of DFIG } \\
\hline Parameters & Value \\
\hline Rated power Ps & $2 \mathrm{Mw}$ \\
Pole pairs $\mathbf{p}$ & 2 \\
Rotor resistance $\mathbf{R r}$ & $2.910^{-3} \Omega$ \\
Stator resistance $\mathbf{R s}$ & $2.610^{-3} \Omega$ \\
Mutual inductance $\mathbf{M}$ & $2.510^{-3} \mathrm{H}$ \\
Rotor inductance $\mathbf{L r}$ & $2.58710^{-3} \mathrm{H}$ \\
Stator inductance $\mathbf{L s}$ & $2.58710^{-3} \mathrm{H}$ \\
\hline
\end{tabular}

Table 2. Parameters of Wind Turbine

\begin{tabular}{cc}
\hline Parameters & Value \\
\hline Gearbox coefficient G & 92.6 \\
Moment of inertia J & $1000 \mathrm{Kg} / \mathrm{m} 2$ \\
Viscous friction f & 0.0024 \\
Length of one blade R & $40 \mathrm{~m}$ \\
Air density $\rho$ & $1.225 \mathrm{Kg} / \mathrm{m} 2$ \\
\hline
\end{tabular}

Table 3. The ADRC Parameters

\begin{tabular}{cccccc}
\hline $\mathrm{K}_{\mathrm{p}}$ & 200 & $\mathrm{~K}_{\mathrm{pc}}$ & 100 & $\mathrm{~K}_{\mathrm{pf}}$ & 250 \\
\hline$\beta_{1}$ & 3600 & $\beta_{1 \mathrm{C}}$ & 1200 & $\beta_{1 \mathrm{f}}$ & 2000 \\
$\beta_{2}$ & 3240000 & $\beta_{2 \mathrm{C}}$ & 360000 & $\beta_{2 \mathrm{f}}$ & 1000000 \\
$\mathrm{~b}_{0}$ & $5.8454 * 10^{3}$ & $\mathrm{~b}_{\mathrm{C} 0}$ & $4.14 * 10^{5}$ & $\mathrm{~b}_{\mathrm{f} 0}$ & -400 \\
\hline
\end{tabular}

\section{REFERENCES}

[1] V. Meenakshi, S. Paramasivam, "Control Strategy Used in DFIG and PMSG Based Wind Turbines an Overview", International Journal of Power Electronics and Drive Systems (IJPEDS), Vol. 8, No. 3, pp. 1160-1167, September2017

[2] S. Mensou, A. Essadki, T. Nasser, B. B. Idrissi, "An Efficient Nonlinear Backstepping Controller Approach of a Wind Power Generation System Based on a DFIG”. International Journal of Renewable Energy Research, Vol.7, No 4, pp. 1520-1528, December 2017.

[3] I. Minka, A. Essadki, S. Mensou \& T. Nasser, "Power Control of a DFIG Driving by Wind Turbine: Comparison Study Between ADRC and PI Controller", Proceeding of the 5th International Renewable and Sustainable Energy Conference (IRSEC), December 2017.

[4] S. Mensou, A. Essadki, T. Nasser \& B. B. Idrissi, "A Robust Speed Control of a Doubly Fed Induction Generator Using in WECS by the Nonlinear Backstepping Controller". Proceeding of the 3rd International Conference on Electrical and Information Technologies (ICEIT), pp. 1-6, November 2017.

[5] V. Gevorgian, Y. Zhang and E. Ela, "Investigating the Impacts of Wind Generation Participation in Interconnection Frequency Response," in IEEE Transactions on Sustainable Energy, vol. 6, no. 3, pp. 1004-1012, July 2015

[6] Y. Wang, G. Delille, H. Bayem, X. Guillaud and B. Francois, "High Wind Power Penetration in Isolated Power Systems-Assessment of Wind Inertial and Primary Frequency Responses," in IEEE Transactions on Power Systems, vol. 28, no. 3, pp. 2412-2420, Aug. 2013.

[7] X. Yingcheng, T. nengling, "System frequency regulation investigationin doubly fed induction generator (DFIG)"WSEAS Transactions on Power systems, Vol. 7, No. 1, pp. 18-26. 2012.

[8] I. Minka, A. Essadki,T. Nasser, "The ADRC linear power control applied to the wind turbine system based on DFIG", ARPN Journal of Engineering and Applied Sciences, Vol.13,No. 14, pp.4378-4386, July 2018.

[9] A. Rahab, F. Senani, \& H. Benalla,"Direct power control of brushless doubly-fed induction generator used in wind energy conversion system". International Journal of Power Electronics and Drive Systems (IJPEDS), Vol. 8, No. 1, pp. 417-433, 2017.

[10] S. Mensou, A. Essadki, I. Minka, T. Nasser \& B. B. Idrissi, "Backstepping Controller for a Variable Wind Speed Energy Conversion System Based on a DFIG", Proceeding of the 5th International Renewable and Sustainable Energy Conference (IRSEC), December 2017.

[11] R. Chakib, "Commandeavancéed'uneéolienne à base de la MADA envue de sa participation aux services système: réglage de fréquence, réglage de tension et tenue aux creux de tension"PhD. Dissertation, Dept. Elect. Eng., Mohammed V University, Mohammadia School of Engineers, Rabat, Morocco, 2017.

[12] Y. Wang, "Evaluation de la performance des réglages de fréquence des éoliennes à l'échelle du système électrique: Application à un cas insulaire", PhD.Dissertation, Dept. L2EP, Central School of Lille, French, November 2012.

[13] A. Molina-García, I. Muñoz-Benavente, A. D. Hansen and E. Gómez-Lázaro, "Demand-Side Contribution to Primary Frequency Control With Wind Farm Auxiliary Control," in IEEE Transactions on Power Systems, vol. 29, no. 5, pp. 2391-2399, Sept. 2014.

[14] Chengming He and Hongtao Wang, "Research on primary frequency control strategy based on DFIG," IEEE PES Innovative Smart Grid Technologies, Tianjin, 2012, pp. 1-5. doi: 10.1109/ISGT-Asia.2012.6303196

[15] I. Erlich and M. Wilch, "Primary frequency control by wind turbines," IEEE PES General Meeting, Providence, RI, 2010, pp. 1-8. doi: 10.1109/PES.2010.5589911

[16] F. Senani, A. Rahab, \& H. Benalla, "A Complete Modeling and Control for Wind Turbine Based of a Doubly Fed Induction Generator using Direct Power Control”. International Journal of Power Electronics and Drive Systems (IJPEDS), Vol. 8, No. 4, pp. 1954-1962, 2017.

[17] A. Ahmidi, "Participation de parcs de production éolienne au réglage de la tension et de la puissance réactive dans les réseaux électriques", $\mathrm{PhD}$ thesis, Central School of Lille, French, 2010.

[18] X. Yingcheng and T. Nengling, "Review of contribution to frequency control through variable speed wind turbine, Renewable Energy," Renewable Energy. Vol. 36 (6), pp. 1671-1677, 2011.

[19] S. Yuan-Zhang, Z. Zhao-Sui, L. Guo-Jie, L. Jin, "Review on frequency control of power systems with wind power penetration, Proc", International conference on power systems technology (POWERCON), Hangzhou, pp. 1-8,2010. 
[20] A. Aziz, G. Shaliullah, A. Stojcevski, M. Amanullah, "Participation of DFIG based wind energy system in load frequency of interconnected multigeneration power system", Australasian universities power engineering conference AUPEC, Curtin university, Perth Australia, pp. 1-6, 2014.

[21] Y. Zhu, S. Li, "Participation to frequency regulation of wind power system with spinning reserve control to permanent magnet synchronous generators (PMSGs)", renewable power generated conference (RPG2013), Beijing, pp. 1-4, September 2013.

[22] M. El Azzaoui, H. Mahmoudi, K. Boudaraia, "Backstepping Control of wind and photovoltaic hybrid Renewable Energy System”. International Journal of Power Electronics and Drive Systems (IJPEDS), Vol.7, pp. 677-686, 2016.

[23] X. Yingcheng and T. Nengling, "System frequency regulation in doubly fed induction generator (DFIG)", International Journal of Electrical Power \& Energy Systems (IJPEDS), Vol. 43.1, pp. 977-983, 2012.

[24] N. Khezami, "Commandemultimodèleoptimale des éoliennes: Application à la participation des éoliennes au réglage de la fréquence", PhD Thesis. Ecole Centrale de Lille, 2011.

\section{BIOGRAPHIES OF AUTHORS}

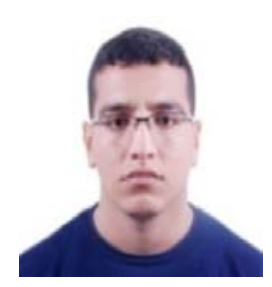

IssamMinka was born in Khenifra, Morocco. He holds a master's degree in Science and Technology entitled Microelectronic Systems of Telecommunications and Industrial Computing at the Faculty of Science and Technology of Fez, Morocco in 2014. He is currently working on a doctoral thesis in the Electrical Engineering Department of ENSET, Mohammed V University Rabat. His research interests include renewable energy, machine control and electrical systems.

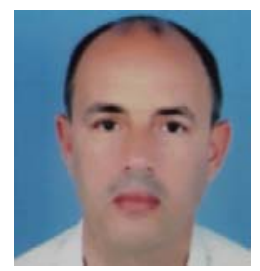

Ahmed Essadki was born in Morocco. He received the $\mathrm{PhD}$ degree in 2000 at Mohammadia Engineering School (EMI), Rabat in 2000. From 1990 to 1993, he pursued the Master program at UQTR University, Quebec Canada, in electrical engineering. His current researches include renewable energy, motor drives and power system. Ahmed is a member of RGE Lab in research group leader. Currently, he is a Professor at the electrical engineering department of ENSET, Rabat.

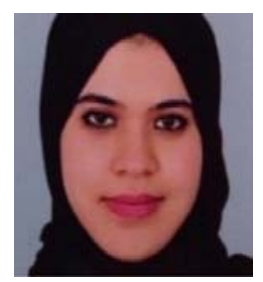

Sara Mensou was born on 1992 in Rabat, Morocco. He received the master's degree in industrial Automation Systems Engineering from Sidi Mohamed Ben Abdellah University, Fez, in 2015. She is currently pursuing $\mathrm{PhD}$ degree in renewable energy, motor drives and power system at Electrical Engineering Research Laboratory, ENSET, Mohammed V University, Rabat, Morocco. She is main area of research includes contribution to the control of the generators applied in wind turbines and dSPACE based control systems

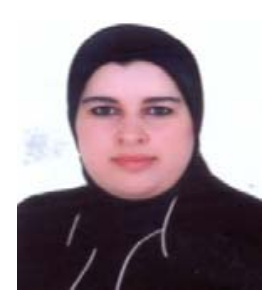

Tamou Nasser was born in Morocco. She received the PhD degree in 2005 and her research MS degree in 2000, all in electrical engineering from Mohammadia Engineering School (EMI), Morocco. Her current research interests include renewable energy and motor drives. She is amember of Al Jazari research group. Currently, she is a Professor at the communication networks department of ENSIAS, Mohammed V University Rabat, Morocco. 